\title{
Distribution and a New Locality Record of the Invasive Asian Wasp, Sceliphron curvatum (F. Smith, 1870) (Hymenoptera: Sphecidae) in Europe and Turkey
}

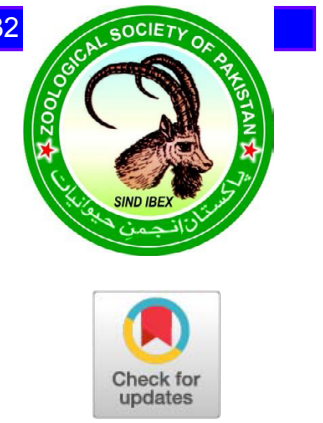

\author{
Ömer Ertürk and Beyhan Taş* \\ Department of Molecular Biology and Genetics, Faculty of Arts and Sciences, Ordu \\ University, Cumhuriyet Campus, 52200 Ordu, Turkey.
}

\begin{tabular}{l} 
Article Information \\
\hline Received 23 July 2018 \\
Revised 21 June 2019 \\
Accepted 28 September 2020 \\
Available online 25 Februay 2021 \\
(early access) \\
Published 10 December 2021 \\
Authors' Contribution \\
BT collected samples in the field and \\
analysed the literature. ÖE and BT \\
organised the work plan and wrote the \\
manuscript. \\
Key words \\
Invasive alien species, Antropofil, \\
Biological invaders, Mud dauber, \\
Sinantropic
\end{tabular}

\section{A B S T R A C T}

In this study, the distribution of Sceliphron curvatum F. Smith, 1870 (Hymenoptera: Apocrita, Sphecidae) has been reported in Eroupe and Turkey. S. curvatum is an invasive species. Rapidly spreading to Europe from Southeast Asia. It is distributed throughout Europe today. There are also records from transoceanic America continent. For anthropophilic S. curvatum species, the first record was made from Turkey, in 2015. In this study, a new locality record was made for this species from the province of Ordu, which is in Central Black Sea Region on the coast of South Black Sea. This wasp species, which has very important role in the functioning of ecosystem, just like other bees, is not aggressive and it does not harm people.

\section{INTRODUCTION}

$\mathrm{T}$ here is a complexity regarding the taxonomical differences between hornets and other wasps of the family Vespidae, particularly the yellow jackets which are members of an identical subfamily. There are about 300 alien Hymenoptera species belonging to 30 families in Europe. Sphecidae family in this group consists of approximately 70 species and all of the species are alien. It is stated that four species from this family, Sceliphron caementarium (Drury, 1773) and Isodontia mexicana (de Saussure, 1867) are of North America origin, while $S$. curvatum (Smith, 1870) and S. deforme (Smith, 1856) are of Asia origin and they are alien species coming to Europe accidentally (Rasplus et al., 2010). Recently, the rapid spread of Sceliphron curvatum (Hymenoptera: Apocrita, Sphecidae) wasp, which is an invasive species, in Europe has attracted attention. This species is sinantropic, the origin of which is the mountainous areas of Asia (North India, Nepal, Pakistan, Kazakhstan, Tajikistan, etc.) and was first recorded in Europe in a village in the South east of Austria (Grätsch) in 1979 (Vecht, 1984). Mud dauber wasp first spread to Central and Southern Europe is today spread in the whole Europe. While S. curvatum forms

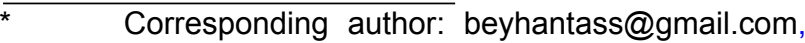
beyhant@odu.edu.tr 0030-9923/2022/0001-0315 \$ 9.00/0

Copyright 2022 Zoological Society of Pakistan
}

strong populations especially in towns and villages of South and Central Europe (Schmid-Egger, 2005; Bitsch and Barbier, 2006; Bitsch, 2010), it also has been recorded in the Alpines (Tyrol, Austria) (Schedl, 2016). This species is reported to reach from Middle East to the South and east of Ukraine which is in Eastern Europe (Crimea and Kharkiv, region) and to be present in almost the whole Ukraine and then advance to Europe (Tymkiv et al., 2015). A great number of scientific studies have reported records of $S$. curvatum species in European countries for more than 20 years. In Turkey, records are very recent and insufficient. Major recorded places for European countries and Turkey are given in Table I. Figure 1 shows the general distribution.

S. curvatum is an anthropophilic species. They generally make their nests in various places of houses and buildings such as ceilings, walls, curtains, clothes, closets, and books (Bitsch and Barbier, 2006). Making nests is one of the main activities of Sceliphron wasps (Chatenoud et al., 2012). Their nests are very special. Nests are made of mud, dry, as separate cylindrical nest series in the shape of barrels (Bitsch, 2010). Nests are full of spiders as in the other species of the genus (Schneider et al., 2014). Females carry paralyzed spiders to each nest as prey and then leave their eggs (Polidori et al., 2007). They close the opening of the hole when they leave the nest (Grandi, 1961). The larvae which get out of the egg grow by eating the prey and become adults.

S. curvatum has a distinctive characteristic chromatically 
since it has some yellow and reddish body parts. Thus, this species is easily recognisable among the other members of Sceliphron species in Europe (Schmid-Egger, 2005). S. curvatum are generally solitary wasps with a moderate to big body. Adults are generally fed with nectars and this way they help the plants to pollinate. Their larvae are carnivorous. Since these wasps are predatory, they also ensure the control of the population of insects and spiders they prey on. Thus, they contribute to biological balance of the nature (Bohart and Menke, 1976). S. curvatum is not aggressive; it does not sting if it is not harmed.

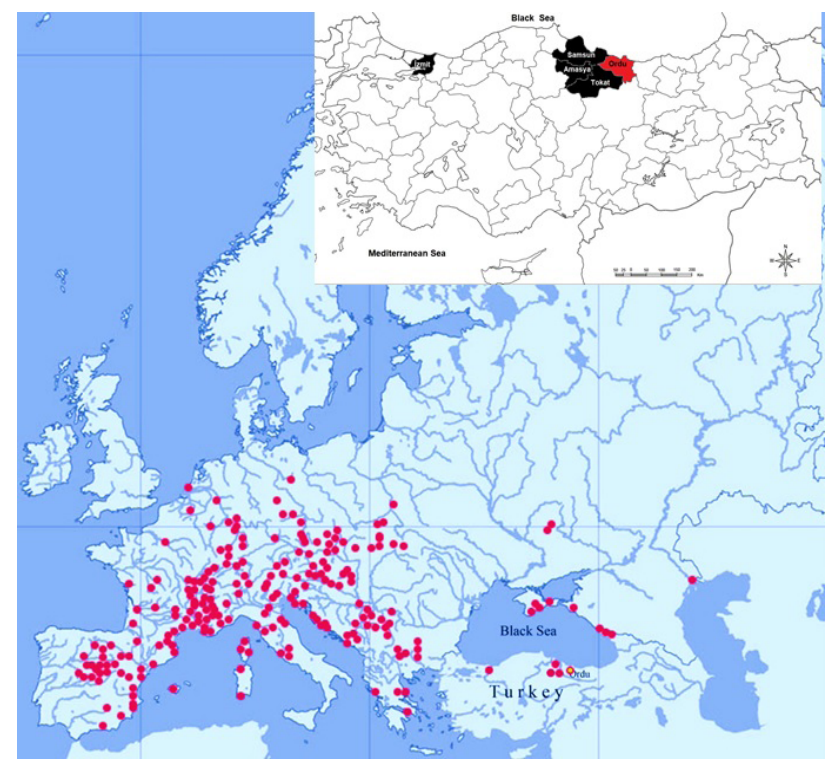

Fig. 1. Distribution of Sceliphron curvatum in Europe and Turkey (Ordu city, new record).

The first record of S. curvatum species in Turkey was from the provinces of Samsun, Tokat (Central Black Sea Region) and İzmit (Eastern Marmara Region) which are on the North of Anatolia (Gülmez and Can, 2015). S. curvatum was also recorded from Samsun, Vezirköprü town, Kunduz Mountains (Yildırım et al., 2016) and Tokat, Erbaa town (Gülmez and Dizer, 2016). This study reports a new locality record for S. curvatum in Turkey from the province of Ordu on South Black Sea shore.

\section{MATERIALS AND METHODS}

S. curvatum samples and nests were collected from the province of Ordu (Fig. 1). Sampling localities: Central Black Sea Region, Ordu, Perşembe, Mersin District, 27 $\mathrm{m}$ altitude above sea level, at $41^{\circ} 06^{\prime} 47^{\prime \prime} \mathrm{N}, 37^{\circ} 46^{\prime} 03^{\prime \prime} \mathrm{E}$ coordinates, 15.VII.2016, 2 q, 10 wasp nests (with larvae). The nests were made on the bed cloth in a wooden village house used as summer house. Four nests were found on the curtain: Central Black Sea Region, Ordu, Perşembe, Ortatepe District, $429 \mathrm{~m}$ altitude above sea level, at $41^{\circ} 03^{\prime} 16^{\prime \prime} \mathrm{N}, 37^{\circ} 40^{\prime} 56^{\prime}$ "E coordinates, 12.IX.2017 and 06.II.2018, 2 wasp nests and 4 wasp nests (with larvae). The nests were made behind a photo frame in a concrete reinforced village house.

The wasps caught and the clay nests were carefully taken to the laboratory for examination. The mud dauber wasp samples were identified using Schmid-Egger (2005) and Bitsch and Barbier (2006).

\section{RESULTS}

General classification of the species is as follows (Gargominy, 2017; Guala and Döring, 2017):

Order: Hymenoptera Linnaeus, 1758

Suborder: Apocrita

Superfamily: Apoidea

Family: Sphecidae Latreille, 1802

Tribe: Sceliphrini Ashmead, 1899

Genus: Sceliphron Klug, 1801

Species: Sceliphron curvatum (F. Smith, 1870)

Synonyms: Pelopaeus curvatum (F. Smith, 1870)

The examined $S$. curvatum species is morphologically different from wasps which are commonly found in nature. They are big, slender and they have vivid colours. They are between 15 and $22 \mathrm{~cm}$, they are black and they have yellow and red ornaments. The body has the head, thorax and abdomen parts distinctly. The long-cylindrical petiole structure of this species, which is also called slim-waist wasp, is characteristic. S. curvatum's biology is similar to local species. The females build reproduction nests similar to cylindrical barrels from mud. They stick these nests next to each other on a ground with a specific order in places where human beings live. In Perşembe, Mersin samples, 10 nests were found on the bed cloth (Fig. 2). 4 nests were made on the curtain in the same room. When the nests were examined, it was seen that there were spiders placed in each one for the larvae to feed. In these nests, morphologically four different types of spiders were found (Fig. 2). The spiders were paralyzed, dead or fragmented.

Two clay nests in Ortatepe locality were found behind a photo frame, no wasp samples were caught. The colours of the wasp nests in Mersin and Ortatepe were found to be different from each other (Fig. 2). This difference results from the different soil structure where wasp samples live. When the larvae in nests were examined, it was found that the larvae in Mersin sample (summer larvae) were white, while the larvae in Ortatepe sample (autumn larvae) were yellow (Fig. 2). 
Table I. Alien sphecid wasp $S$. curvatum in Europe countries and Turkey.

\begin{tabular}{|c|c|c|}
\hline Countries & Regions & References \\
\hline Austria & Central Europe & $\begin{array}{l}\text { Vecht (1984); Gepp and Bregant (1986); Ebmer (1995); Gepp (1995, 2003); Dollfuss (1991); } \\
\text { Guselneitler (1996a); Dollfuss et al. (1998); Kofler (1998); Schwarz et al. (1999); Schmid-Egger } \\
\text { (2005); Schedl (2015; 2016) }\end{array}$ \\
\hline Belarus & Eastern Europe & Khvir (2014) \\
\hline Belgium & Western Europe & Schneider et al. (2014) \\
\hline Bulgaria & Eastern Europe & $\begin{array}{l}\text { Jacobs (2005); Schmid-Egger (2005); Ljubomirov (2006); Boch (2009); Guéorguiev and } \\
\text { Ljubomirov (2009) }\end{array}$ \\
\hline Croatia & Southern Europe & Gusenleitner (1996b); Straka et al. (2004); Ćetković et al. (2004); Schmid-Egger (2005) \\
\hline Czech Republic & Central Europe & Straka et al. (2004); Bogusch et al. (2004, 2005); Dobosz (2010); Janšta and Bogusch (2017) \\
\hline France & Western Europe & $\begin{array}{l}\text { Gonseth et al. (2001); Vernier (2003); Carrière (2004, 2005, 2009, 2010); Rahola (2003, 2005); } \\
\text { Dumon (2006); Bitsch and Barbier (2006); Magdalou (2006); Bitsch (2010); Bitsch et al. (2013) }\end{array}$ \\
\hline Germany & Central Europe & $\begin{array}{l}\text { Ohl (2001); Dorow and Jäger (2004); Schmid-Egger (2005); Reder (2006, 2007); Schardt et al. } \\
\text { (2012); Köhler et al. (2014) }\end{array}$ \\
\hline Greece & Southern Europe & Schmid-Egger (2005); Standfuss and Standfuss (2006) \\
\hline Hungary & Central Europe & Józan (1998, 2002, 2006); Fazekas (2012); Szinetár and Fazekas (2015) \\
\hline $\begin{array}{l}\text { Iberian Peninsula } \\
\text { (Spain, Portugal) }\end{array}$ & Western Europe & Gayubo and Izquierdo (2006); Castro $(2007,2010)$ \\
\hline Italy/Sicily/Malta & Southern Europe & $\begin{array}{l}\text { Scaramozzino (1995, 1996); Strumia (1996); Grillenzoni and Pesarini (1998); Pagliano (2000); } \\
\text { Pagliano et al. (2000); Schmid-Egger (2003); Hellrigl (2001, 2004, 2005); Jacobi (2005); } \\
\text { Pagliano and Negrisolo (2005); Polidori et al. (2007); Cillo et al. (2009); Pagliano (2009); } \\
\text { Olivieri (2010); Ceccolini and Paggetti (2011); Strumia et al. (2012); Di Giovanni et al. (2017); } \\
\text { Turrisi and Altadonna (2017) }\end{array}$ \\
\hline Lithuania & Eastern Europe & Budrys and Orlovskytė (2016) \\
\hline Luxembourg & Western Europe & Schneider et al. (2014); Ries and Pfeiffenschneider (2017) \\
\hline Montenegro & Southern Europe & Ćetković et al. (2004) \\
\hline Poland & Central Europe & Bury et al. (2009); Wiśniowski et al. (2013); Bilański et al. (2014) \\
\hline Romania & Eastern Europe & Popescu (2014) \\
\hline Russia (European) & Eastern Europe & Prokofiev and Skomorokhov (2010) \\
\hline Serbia & Southern Europe & Ćetković et al. (2004) \\
\hline Slovakia & Central Europe & Lukas (2003); Bogusch et al. (2005) \\
\hline Slovenia & $\begin{array}{l}\text { Central-South- } \\
\text { ern Europe }\end{array}$ & Gogala (1995) \\
\hline Switzerland & Central Europe & Gonseth et al. (2001); Vernier (2003) \\
\hline Turkey & $\begin{array}{l}\text { Eastern Europe } \\
\text { Western Asia }\end{array}$ & Gülmez and Can (2015); Gülmez and Dizer (2016); Yıldırım et al. (2016) \\
\hline Ukraine & Eastern Europe & $\begin{array}{l}\text { Shorenko (2003, 2007); Shorenko and Konovalov (2010); Ćetković et al. (2011); Fateryga and } \\
\text { Kovblyuk (2013); Popov and Khomitskii (2014); Tymkiv et al. (2015); Mokrousova and Popov } \\
\text { (2016) }\end{array}$ \\
\hline
\end{tabular}

\section{DISCUSSION}

A great number of Asian origin sphecid S. curvatum wasps have been reported to be invasive in Europe. They spread rapidly to Austria at the end of 70s and to Southern Europe (especially south eastern Greece and the area around Montpellier on the South of France). S. curvatum showed a trend of expansion to the North of Europe from the South after 2000s (Schmid-Egger, 2005; Bitsch and Barbier, 2006). New declarations are made for this species from Transoceanic and America (Barrera-Medina and Garcete-Barrett, 2008; Compagnucci and Roig-Alsina, 2008; Ramage et al., 2015; Ramage, 2017). None of 
the $S$. caementarium and $S$. curvatum species, which are allochthonous species, are brought to Europe on purpose; however, they may have come through passive transport, especially through nests that can be made on materials used for packaging (Strumia, 1996). It is strongly supported hypothesis that all the types of this species are distributed through passive transport and that these species have an ecological characteristic. Even if the ecological and/or etiological characteristics of a species endorse a strong distribution power to it, this advantage is not enough to ensure it to expand from its first distribution area (building steady populations in new areas). Other conditions should also be fulfilled (Ceccolini and Paggetti, 2011). The fact that the expansion of alien species' distribution areas in Europe corresponds to especially warm years shows that climate factors have an important role (Vernier et al., 1996). "Sinantropic degree" of each species is not certainly insignificant in winter periods because they prefer buildings (headlining, basements, warehouses, stables, etc.) in order to protect from extreme colds (frost) (Gonseth et al., 2001).

When the distribution of $S$. curvatum species throughout Europe is analysed in terms of chronological order in scientific studies, it can be seen that it is distributed in Slovenia, south western Hungary, westernmost Croatia, northern Serbia, central Bulgaria, coastal Montenegro, central (coastal) Greece and Romania in south eastern Europe (Ćetković et al., 2011). The reason why this species was not recorded in Turkey until 2015 although it was recorded in Balkans at the end of 90s (it was recorded in Bulgaria in 1997) is not due to the expansion gap of the species, it is just due to the insufficiency of the number of researchers who make researches on this group spatially or the insufficiency of samples. The first records were in the provinces of Amasya, Samsun, Tokat and Kocaeli (İzmit) in Turkey (Gülmez and Can, 2015). $3 \circ$ and $1 \delta$ S. curvatum records were made from Samsun, Vezirköprü, Kunduz Mountain in 2014 (Yildırım et al., 2016). This study reports 2 q records caught in July 2016 from Ordu, Perşembe, Mersin district on the east of Samsun. When the distribution of $S$. curvatum samples for Turkey is examined, it can be seen that they are distributed close to Black Sea coast on the north of Turkey and Central Black Sea Region (Fig. 2). Ordu and Samsun are important port cities in the coast of Southern Black Sea. These wasps can probably have been transported to these ports passively with loads coming by ship from Russia and Ukraine. As a conclusion, the place where the highest numbers of records are made for $S$. curvatum species in Turkey is Central Black Sea. It is possible to find out the presence of this species in different regions of Turkey, which is in mild temperature zone. Future studies should find out new localities of this species throughout Turkey, its expansion should be monitored and population density should be found out during the global climate change process.

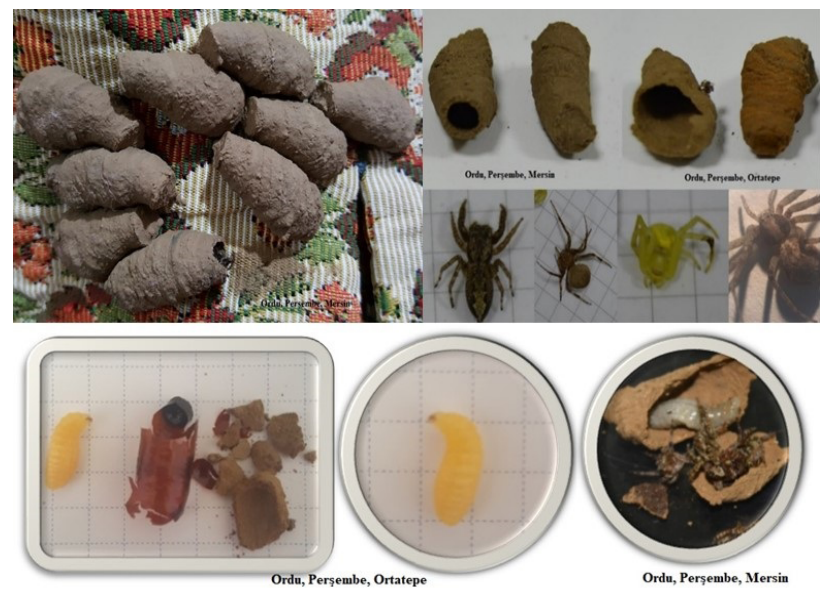

Fig. 2. Sceliphron curvatum nests, larvas and the spiders in the nests.

It should also be remembered that wasps work like ecosystem engineers and that they are an important living being group for the ecosystem because while wasps visit flowers and collect pollens and nectar from them, at the same time they are effective pollinators. This way, they play an active role in both plant production and in the distribution of herbaceous and woody plants. Wasps are in fact a biological agent in fighting some pests in nature. In addition, they provide pollination in plants like other bee types and they contribute to agricultural production. Thus, wasps should not be destroyed in order not to disturb the natural balance.

\section{ACKNOWLEDGEMENT}

We wish to thank Biologist Hazal Şahin for the field work.

\section{Statement of conflict of interest}

The authors have declared no conflict of interest.

\section{REFERENCES}

Barrera-Medina, R. and Garcete-Barrett, B., 2008. Sceliphron curvatum (Smith, 1870) a new species of Sphecidae (Hymenoptera) introduced in Chile. Rev. Chil. Entomol., 34: 63-66.

Bilanski, P., Kolodziej, Z. and Bury, J., 2014. Distribution of Sceliphron curvatum Smith, 1870 (Hymenoptera, Sphecidae) in Poland. Polish J. 
Ent., 83: 109-119. https://doi.org/10.2478/pjen2014-0008

Bitsch, J., 2010. Compléments au volume 2 des Hyménoptères Sphecidae d'Europe occidentale (Faune de France 82). Bull. Soc. Ent. Fr., 115: 99136.

Bitsch, J. and Barbier, Y., 2006. Répartition de l'espèce invasive Sceliphron curvatum (F. Smith) en Europe et plus particulièrement en France (Hymenoptera, Sphecidae). Bull. Soc. Ent. Fr., 111: 227-237.

Bitsch, J., Grouet, G. and Savina, H., 2013. Sphéciformes des Pyrénées centrales: découverte en Ariège de l'espèce boréo-alpine Crabro lapponicus Zetterstedt (Hymenoptera, Aculeata). Bull. Soc. Ent. Fr., 118: 289-300.

Boch, A., 2009. Sphecidae, Sceliphron curvatum from Bulgaria. HymIS forum. Available at: http://www. forum.hymis.de/viewtopic.php?f=18andt=2660 (accessed: 8 Jan 2018).

Bogusch, P., Liška, P., Lukáš, J. and Dudich, A., 2005. Spreading and summary of the knowledge of the invasive sphecid wasp Sceliphron curvatum (Smith 1870) in the Czech Republic and Slovakia (Hymenoptera: Apocrita, Sphecidae). Linzer. Biol. Beitr., 37: 215-221.

Bogusch, P., Straka, J. and Srba, M., 2004. The sphecid wasp from the Botanical Garden in Prague. Živa, 51: 121-122.

Bohart, R.M. and Menke, A.S., 1976. Sphecid wasps of the world: A generic revision. Univ. of California Press, Berkeley, CA.

Budrys, E. and Orlovskytè, S., 2016. First record of alien mud dauber wasp Sceliphron curvatum in Lithuania (Hymenoptera: Sphecidae). New Rare Lithuania Insect Sp., 28: 94-96.

Bury, J., Sudoł, D. Zięba, P. and Żyła, W., 2009. New data of occurrence of the genus Sceliphron Klug, 1801 (Hymenoptera, Sphecidae) in Poland. Acta Ent. Siles., 17: 11-18.

Carrière, J., 2004. A propos de Sceliphron curvatum (F. Smith, 1870) dans l'Hérault-Mythe ou réalité? (Hymenoptera, Sphecidae). Lambillionea, 104: 159-164.

Carrière, J., 2005. Sceliphron curvatum (Smith, 1870) dans l'Hérault: note étho-biologique complémentaire (Hymenoptera, Sphecidae). Lambillionea, 105: 257-262.

Carrière, J., 2009. Sceliphron curvatum (F. Smith, 1870). en Lozère! Note iconographique (Hymenoptera, Sphecidae). Lambillionea, 109: 73-78.

Carrière, J., 2010. Sceliphron curvatum (F. Smith, 1870) dans 1'Hérault: Rectificatif et complément
(Hymenoptera, Sphecidae). Lambillionea, 110: 8387.

Castro, L., 2007. Nuevos datos sobre la expansión de Sceliphron curvatum (Smith 1870) en la Península Ibérica (Hymenoptera: Sphecidae). Bol. Soc. Ent. Aragon., 40: 537-538.

Castro, L., 2010. Novedades sobre la distribución de Sceliphron curvatum (Smith 1870) en la Península Ibérica y Baleares (Hymenoptera: Sphecidae). Bol. Soc. Ent. Aragon., 47: 437-439.

Ceccolini, F. and Paggetti, E., 2011. Notes on the distribution of Italian Sceliphron, with new chorological data for the allochthonous species (Insecta Hymenoptera Sphecidae). Quad. Stud. Nat. Romagna, 34: 111-118.

Ćetković, A., Mokrousov, M., Plećaš, M., Bogusch, P., Antić, D., Đorović-Jovanović, L., Krpo-Ćetković, J., Karaman, M., 2011. Status of the potentially invasive Asian species Sceliphron deforme in Europe, and an update on the distribution of $S$. curvatum (Hymenoptera: Sphecidae). Acta Ent. Serb., 16: 91-114.

Ćetković, A., Radović, I., Đorović, L., 2004. Further evidence of the Asian mud-daubing wasps in Europe (Hymenoptera: Sphecidae). Ent. Sci., 7: 225-229. https://doi.org/10.1111/j.1479-8298.2004.00067.x

Chatenoud, L., Polidori, C., Federici, M., Licciardi, V. and Andriett, F., 2012. Mud-ball construction by Sceliphron mud-dauber wasps (Hymenoptera: Sphecidae): a comparative ethological study. Zool. Stud., 51: 937-945.

Cillo, D., Fois, F., Bazzato, E. and Piras, P., 2009. Segnalazioni faunistiche Italiane 491-Sceliphron curvatum (Smith, 1870) (Hymenoptera Sphecidae). Boll. Soc. Ent. Ital., 141: 113-118.

Compagnucci, L.A. and Roig Alsina, A., 2008. Sceliphron curvatum, a new invasive wasp in Argentina (Hymenoptera, Sphecidae). Rev. Soc. Ent. Argent., 67: 65-70.

Di Giovanni, F., Mei M. and Cerretti, P., 2017. Vertical stratification of selected Hymenoptera in a Remnant Forest of the Po Plain (Italy, Lombardy) (Hymenoptera: Ampulicidae, Crabronidae, Sphecidae). Fragm. Ent., 49: 71-77. https://doi. org/10.4081/fe.2017.233

Dobosz, R., 2010. The first record of Sceliphron curvatum (Smith, 1870) (Hymenoptera: Sphecidae) in Upper Silesia. Acta Ent. Siles., 18: 89.

Dollfuss, H., 1991. Bestimmungsschlüssel der Grabwespen Nord- und Zentraleuropas. Hymenoptera, Sphecidae (mit speziellen Angaben zur Grabwespenfauna Osterreichs). Stapfia, 24: 
$1-247$.

Dollfuss, H., Gusenleitner, J. and Bregant, E., 1998. Grabwespen in Burgenland (Hymenoptera: Sphecidae). Stapfia, 55: 507-552.

Dorow, W.H.O. and Jäger, P., 2004. Zum nahrungsspektrum der grabwespe Sceliphron (Hensenia) curvatum (Smith, 1870) (Hymenoptera: Sphecidae). BembiX, 19: 37-40.

Dumon, D., 2006. Capture de Sceliphron curvatum dans le département de I'Ain (Hymenoptera Sphecidae). Bull. Mens. Soc. Linn. Lyon, 75: 109-110. https:// doi.org/10.3406/linly.2006.13620

Ebmer, A.W., 1995. Hymenopterologische notizen aus Österreich-2 (Insecta: Hymenoptera aculeata). Linzer Biol. Beitr., 27: 273-277.

Fateryga, A.V. and Kovblyuk, M.M., 2013. Nesting ecology of the digger wasp Sceliphron curvatum (F. Smith, 1870) (Hymenoptera, Sphecidae) in Ukraine. Evraziat Ent. Z., 12: 309-314.

Fazekas, I., 2012. New record of Sceliphron curvatum (Smith, 1870) in Mecsek Mountains (SW Hungary) (Hymenoptera, Sphecidae). e-Acta Nat. Pannon., 4: 69-72.

Gargominy, O., 2017. TAXREF. Version 4.3. SPN Service du Patrimoine naturel, Muséum national d'Histoire naturelle, Paris. Available at: https://doi. org/10.15468/vqueam (accessed: 21 Dec 2017).

Gayubo, S. and Izquierdo, I., 2006. Presencia de la especie invasora Sceliphron curvatum (F. Smith 1870) en la Península Ibérica (Hymenoptera: Apoidea: Sphecidae). Bol. Soc. Ent. Aragon., 39: 257-260.

Gepp, J., 1995. Die orientalische mauerwespe Sceliphron curvatum (Smith 1870): biologie und ausbreitungsgeschichte in Ostösterreich (Hymenoptera, Sphecidae). Stapfia, 37: 153-166.

Gepp, J., 2003. Verdrängt die eingeschleppte mauerwespe Sceliphron curvatum autochthone Hymenopteren im Sü̈ osten Österreichs? Ent. Austr., 8: 18.

Gepp, J. and Bregant, E., 1986. Zur biologie der synanthropen, in Europa eingeschleppten orientalischen mauerwespe Sceliphron (Prosceliphron) curvatum (Smith, 1870) (Hymenoptera: Sphecidae). Mitt. Naturwiss. Ver. Steiermark, 116: 221-240.

Gogala, A., 1995. Two non-European species of Sphecidae recorded also in Slovenia (Hymenoptera: Sphecidae). Acta Ent. Sloven., 3: 73-75

Gonseth, Y., Imbeck, P. and Tussac, M., 2001. Sceliphron curvatum (Smith, 1870), une espèce nouvelle de la faune Suisse et de la faune de France (Hymenoptera
Sphecidae). Mitt. Schweiz. Ent. Ges., 74: 99-103.

Grandi, G., 1961. Studi di un Entomologo Sugli Imenotteri Superiori. Calderini, Bologna.

Grillenzoni, G. and Pesarini. F., 1998. Due nuovi Sfecidi della fauna esotica rinvenuti a Ferrara (Hymenoptera Sphecidae). Ann. Mus. Civ. St. Nat. Ferrara, 1: 83-85.

Guala, G. and Döring, M., 2017. Sceliphron curvatum (F. Smith, 1870). Integrated taxonomic information system (ITIS). National Museum of Natural History, Smithsonian Institution. Available at: (accessed: 21 Dec 2017).

Guéorguiev, B.V. and Ljubomirov, T., 2009. Coleoptera and Hymenoptera (Insecta) from Bulgarian section of Maleshevska Planina Mountain: study of an until recently unknown biodiversity. Acta Zool. Bulg., 61: 235-276.

Gusenleitner, J., 1996a. Hymenopterologische Notizen aus Österrreich-4 (Insecta: Hymenoptera aculeata). Linzer Biol. Beitr., 28: 5-13.

Gusenleitner, J., 1996b. Kurzbericht über Sphecinae in Istrien (Croatia) (Hymenoptera, Sphecidae). Linzer Biol. Beitr., 28: 817-819.

Gülmez, Y. and Can, İ., 2015. Firt record of Sceliphron (Hensenia) curvatum (Hymenoptera: Sphecidae) from Turkey with notes on its morphology and biology. North-West J. Zool., 11: 174-177.

Gülmez, Y. and Dizer, A., 2016. Determination of the fauna of Sphecidae (Insecta: Hymenoptera) of Tokat province. Kafkas Univ. J. Sci., 9: 55-62.

Hellrigl, K., 2001. Orientalische MörtelgrabwespeSceliphron curvatum (F. Smith 1870). Gredleriana, 1: 466-468.

Hellrigl, K., 2004. Zur Verbreitung eingeschleppter Grabwespen (Hymenoptera, Sphecidae) in Südtirol und Norditalien. Forest Observer, 1: 181-196.

Hellrigl, K., 2005. Die orientalische Mörtelwespe Sceliphron curvatum (F. Smith, 1870) in Südtirol. BembiX, 19: 29-34.

Jacobi, B., 2005. Sceliphron (Hensenia) curvatum (Smith, 1870) neu für Nordrhein-Westfalen. Bembix, 19: 35.

Jacobs, H.J., 2005. Lindenius anatolicus Beaumont 1967-Erstnachweis in Europa und weitere Angaben zur Grabwespenfauna Bulgariens (Hymenoptera: Sphecidae, Crabronidae). Linzer Biol. Beitr., 37: 435-456.

Janšta, P., Bogusch, P., 2017. Mapa rozšíření Sceliphron curvatum v České republice. In: Biological libraryBioLib (ed. O. Zicha) . Available at: https://www. biolib.cz/cz/taxonmap/id239/ (accessed: 26 Dec 2017). 
Józan, Zs., 1998. The Aculeata fauna of the Duna-Dráva National Park, Hungary (Hymenoptera, Aculeata). Dun. Dolg., 9: 291-327.

Józan, Z-s., 2002. Faunistical, zoogeographical and ecofaunistical investigation on the Sphecoids fauna of the Mecsek Montains (Hymenoptera, Sphecoidea). Nat. Somogyiensis, 3: 45-56.

Józan, Z-s., 2006. New data to the Aculeata fauna of the Zselic hills (Hymenoptera, Aculeata). Somogyi Múz. Közl., 17: 169-182.

Khvir, V.I., 2014. Sceliphron curvatum (Hymenoptera, Sphecidae)-new species of Sphecoidea for Belarus fauna. Proc. Belarusian State Univ., Ser. Physiol. Biochem. Mol. Biol. Sci. Sci. J., 9: 91-94.

Kofler, A., 1998. Die orientalische mauerwespe (Sceliphron curvatum). Ostt. Heimatbl., 66: 1-2.

Köhler, G., Creutzburg, F. and Loxdale, H.D., 2014. Further observations of the Oriental potter wasp, Sceliphron curvatum (F. Smith, 1870), from Jena, Thuringia, Germany (Insecta: Hymenoptera: Sphecidae). Thür. Faun. Abh., 19: 117-122.

Levărdă, A.F. and Matache, I., 2016. The catalogue of Romanian Sphecidae (Hymenoptera: Apoidea: Sphecidae) from the collection of "Grigore Antipa" National Museum of Natural History (Bucharest). Trav. Mus. natl. Hist. Nat. Grigore Antipa, 58: 37-46. https://doi.org/10.1515/ travmu-2016-0002

Ljubomirov, T., 2006. A survey of the faunistic investigations on the Hymenopteran Families Siricidae, Orussidae, Stephanidae, Chrysididae, Bethylidae, Sapygidae, Scoliidae, Tiphiidae, Mutillidae, Pompilidae, Sphecidae, and Crabronidae from the Western Rhodopes-Bulgaria and Greece (Insecta Hymenoptera). In: Biodiversity of Bulgaria, 3. Biodiversity of Western Rhodopes (Bulgaria and Greece) (ed. P. Beron). I. Pensoft and National Museum of Natural History, Sofia. pp. 524-545.

Lukáš, J., 2003. Fauna of Hymenoptera of an old fruit orchard in Bratislava. Fol. Faun. Slov., 8: 71-74.

Magdalou, J-A., 2006. Inventaire des Hyménoptères Sphecidae, Réserve Naturelle de la Forêt de la Massane Travaux 75. Laboratoire Arago, Banyulssur-Mer, Cedex.

Mokrousov, M.V. and Popov, I.B., 2016. Digger wasps (Hymenoptera, Apoidea: Ampulicidae, Sphecidae, Crabronidae) of the Black Sea Coast of Krasnodar Territory, Abkhazia, and adjacent areas. Ent. Rev., 96: 559-599. https://doi.org/10.1134/ $\mathrm{S} 0013873816050055$
Ohl, M., 2001. Sphecidae. In: Entomofauna Germanica 4 (eds. H. Dathe, A. Taeger and S.M. Blank). Dresden. pp. 137-143.

Olivieri, N., 2010. Segnalazioni Faunistiche Italiane: 501- Sceliphron curvatum (Smith, 1870) (Hymenoptera Sphecidae). Boll. Soc. Ent. Ital., 142: 135.

Pagliano, G., 2000. Catalogo degli Imenotteri italiani II. Sphecidae. Boll. Mus. Reg. Sei. Natur. Torino, 8: 53-141.

Pagliano, G., 2009. Segnalazioni inedite di Sphecidae (Hymenoptera) del Piemonte ed altre regioni italiane. Riv. Piemont. St. Nat., 30: 173-192.

Pagliano, G. and Negrisolo, E., 2005. Hymenoptera: Sphecidae (Fauna d'Italia 40). Calderini, Bologna.

Pagliano, G., Scaramozzino, P.L. and Strumia, F., 2000a. Insediamento di tre specie alloctone di Imenotteri Sfecidi nell'area tirrenica. Environ. ident. Méditerr., Interreg II, Corte, 2: 213-216.

Pagliano, G., Scaramozzino, P.L. and Strumia, F., 2000b. Introduction and spread of four aculeate Hymenoptera in Italy, Sardinia and Corsica. In: Hymenoptera: Evolution, biodiversity and biological control (eds. A.D. Austin and M. Dowton). CSIRO Publishing, Canberra, Australia. pp. 290-295.

Polidori, C., Federici, M., Pesarini, C. and Andrietti, F., 2007. Factors affecting spider prey selection by Sceliphron mud-dauber wasps (Hymenoptera: Sphecidae) in northern Italy. Anim. Biol., 57: 1128. https://doi.org/10.1163/157075607780002005

Popescu, I.E., 2014. First record of Sceliphron curvatum (Smith, 1870) and new data about the distribution of $S$. caementarium (Drury, 1770) in Romania (Hymenoptera: Sphecidae), 58. Proc. 6 ${ }^{\text {th }}$ Int. Zool. Cong. Grig. Antipa Mus., 19-22 November 2014, Bucharest, Romania.

Popov, I.B. and Khomitsky, E.E., 2014. On the digger wasps fauna, distribution and ecology of the genus Sceliphron (Hymenoptera, Sphecidae) in Krasnodar territory. Proc. Kuban State Agrar. Univ., 5: 91-96.

Prokofiev, A.M. and Skomorokhov, M.O., 2010. Sceliphron curvatum (F. Smith, 1870), a new in the fauna of Russia and invasive species of digger wasps (Hymenoptera: Sphecidae). Russian Ent. J., 19: 67-70. https://doi.org/10.15298/rusentj.19.1.11

Rahola, P., 2003. Sceliphron curvatum (Smith, 1870) (Hymenoptera: Sphecidae), une espèce nouvelle pour la faune du Gard. Bull. Soc. Étude Sci. Nat. Nîmes, 64: 57-58.

Rahola, P., 2005. Observations sur la biologie de Sceliphron curvatum (Smith, 1870) dans le Gard 
(sud de la France) (Hymenoptera, Sphecidae). Bull. Soc. Ent. Fr., 110: 331-336.

Ramage, T., 2017. Checklist of the terrestrial and freshwater arthropods of French Polynesia (Chelicerata; Myriapoda; Crustacea; Hexapoda). Zoosystema, 39: 213-225. https://doi. org/10.5252/z2017n2a3

Ramage, T., Charlat, S. and Jacq, F., 2015. The Aculeata of French Polynesia. III. Sphecidae, with the record of three new species for the Society Islands (Hymenoptera). Bull. Soc. Ent. Fr., 120: 157-163.

Rasplus, J-Y., Villemant, C., Paiva, M.R., Delvare, G. and Roques, A., 2010. Hymenoptera. BioRisk, 4: 669-776. https://doi.org/10.3897/biorisk.4.55

Reder, G., 2006. Die orientalische mauerwespe Sceliphron curvatum (F. Smith, 1870) nun auch in Rheinland-Pfalz nachgewiesen (Hymenoptera: Sphecidae). Pollichia-Kurier, 22: 15-17.

Reder, G., 2007. Zum schlupfverlauf und zur generationsfolge der orientalischen mörtelwespeSceliphron curvatum (F. Smith)-in einer mittelgrossen nestaggregation (Hymenoptera: Sphecidae). Fauna Flora Rheinl.-Pfalz, 11: 71-78.

Ries, C. and Pfeiffenschneider, M., 2017. Sceliphron curvatum (F. Sмiтн, 1870). In: Invasive alien species in Luxembourg. Available at: https://neobiota.lu/sceliphron-curvatum/ (accessed: 26 Dec 2017).

Scaramozzino, P.L., 1995. Nuovi arrivi da Est: Sceliphron (Hensenia) curvatum (Smith) (Hymenoptera Sphecidae). Hy-Men, 6: 9-11.

Scaramozzino, P.L., 1996. Nuova località di cattura di Sceliphron (Hensenia) curvatum (Smith) (Hymenoptera: Sphecidae). Hy-Men, 7: 9.

Schardt, L., Renker, C., Staudt, A. and Reder, G., 2012. Auf stetigem vormarsch: Die aktuelle verbreitung von Sceliphron curvatum (F. Smith, 1870) in Deutschland (Hymenoptera: Sphecidae). Mainz. Nat. Wiss. Arch., 49: 143-164.

Schedl, W., 2015. Stechimmen II im Botanischen Garten Innsbruck (Tirol, Österreich): Artengarnitur, Blütenbesuch, Phänologie (Insecta: Hymenoptera). Linzer Biol. Beitr., 47: 939-954.

Schedl, W., 2016. Die orientalische Moertelwespe Sceliphron curvatum (F. Smith, 1870) (Hymenoptera; Sphecidae) im Bundesland Tirol (Österreich). Linzer Biol. Beitr., 48: 1091-1096.

Schmid-Egger, C., 2003. New records of "Sphecidae" (Hymenoptera: Sphecidae and Crabronidae) from Sicily (Italy) and Malta. Linzer Biol. Beitr., 35: 747-762.

Schmid-Egger, C., 2005. Sceliphron curvatum (F. Smith
1870) in Europa mit einem Bestimmungsschlüssel für die europäischen und mediterranen SceliphronArten (Hymenoptera, Sphecidae). BembiX, 19: 7-28.

Schneider, N., Barbier, Y., Pauly, A. and Christian, S., 2014. Découverte de Sceliphron curvatum (Smith, 1870) en Belgique et au Luxembourg (Insecta, Hymenoptera, Sphecidae). Bull. Soc. Nat. Luxemb., 115: 251-253.

Schwarz, M., Gusenleitner, F. and Mazzucco, K., 1999. Weitere angaben zur bienenfauna Österreichs vorstudie zu einer Gesamtbearbeitung der bienen Österreichs III (Hymenoptera, Apidae). Entomofauna, 20: 461-524.

Shorenko, K.I., 2003. New data on the digger wasps fauna (Apoidea: Sphecidae, Crabronidae) of Ukraine. Kharkov Ent. Soc. Gazette, 10: 96-98.

Shorenko, K.I., 2007. Supplements to the knowledge of the digger-wasp fauna (Hymenoptera, Sphecidae, Crabronidae) of the Crimean Peninsula. Caucasian Ent. Bull., 3: 257-259. https://doi. org/10.23885/1814-3326-2007-3-2-257-259

Shorenko, K.I. and Konovalov, S.V., 2010. New data on the digger wasps (Hymenoptera: Ampulicidae, Sphecidae, Crabronidae) in the fauna of Ukraine. Ukraïn. Entomofau., 1: 9-32.

Standfuss, K. and Standfuss, L., 2006. Zum aktuellen artenbestand der Pemphredininae, Bembicinae und Sphecinae (Hymenoptera: Crabronidae p.p. et Sphecidae) der planar-kollinen vegetationsstufe in SüdostThessalien/Griechland. Entomofauna, 27: 301-314.

Straka, J., Bogusch, P., Tyrner, P. and Vepřek, D., 2004. New important faunistic records on Hymenoptera (Chrysidoidea, Apoidea, Vespoidea) from the Czech Republic. Klapalekiana, 40: 143-153.

Strumia, F., 1996. Accidental introduction of the Nearctic Sceliphron caementarium (Drury) in Pisa province, Italy (Hymenoptera: Sphecidae). Frust. Ent., 19: 176-179.

Strumia, F., Pagliano, G. and Gayubo, S.F., 2012. Hymenoptera Spheciformes observed in San Rossore Reserve (Pisa province, Tuscany, Italy). Atti Soc. Tosc. Sci. Nat. Mem. Ser. B, 119: 55-60.

Szinetár, C., Fazekas, I., 2015. Adatok az invazív Sceliphron curvatum (Smith, 1870) (Sphecidae) dél-magyarországi lárvabölcsőiben előforduló pókfajokról (Araneae). e-Acta Nat. Pannon., 8: 111-116.

Turrisi, G.F. and Altadonna, G., 2017. A report on two alien invasive species of the genus Sceliphron Klug, 1801 (Hymenoptera Sphecidae) from Sicily, 
with a brief faunistic update on the native species. Biodivers. J., 8: 753-762.

Tymkiv, I., Nazaruk, K., Shydlovskyy, I. and Tsaryk, J., 2015. Expansion of mud dauber wasp Sceliphron curvatum (F. Smith, 1870) in Central and Eastern Europe. Visnyk Lviv Univ. Ser. Biol., 70: 181-187.

Vecht van der, J., 1984. Die orientalische mauerwespe, Sceliphron curvatum (Smith, 1870) in der Steiermark, Österreich (Hymenoptera, Sphecidae). Entomofauna, 6/17: 213-219.

Vernier, R., 2003. Le genre Sceliphron (Hymenoptera, Sphecidae) dans le Bassin lémanique et les régions voisines: vers un point de la situation. Bull. Romand Ent., 21: 1-8.

Vernier, R., Barbalat, S. and Gonseth, Y., 1996. Sceliphron destillatorium (ILL.) (Hymenoptera Sphecidae) au Nord des Alpes en 1995. Bull. Romand Ent., 14: 179-183.

Wiśniowski, B., Huflejt, T., Babik, H., Czechowski, W. and Pawlikowski, T., 2013. New records of two alien mud daubers Sceliphron destillatorium (Ill.) and Sceliphron curvatum (Sm.) (Hymenoptera, Sphecidae) from Poland with comments on expansion of their ranges. Fragm. Faun., 56: 25-37. https://doi.org/10.3161/00159301FF2013.56.1.025

Yıldırım, E., Ljubomirov, T., Özbek, H. and Yüksel, M., 2016. New data on Spheciformes fauna (Hymenoptera: Ampulicidae, Sphecidae, Crabronidae) of Turkey. J. Insect Biodivers., 4: 1-51. https://doi. org/10.12976/jib/2016.4.3 